
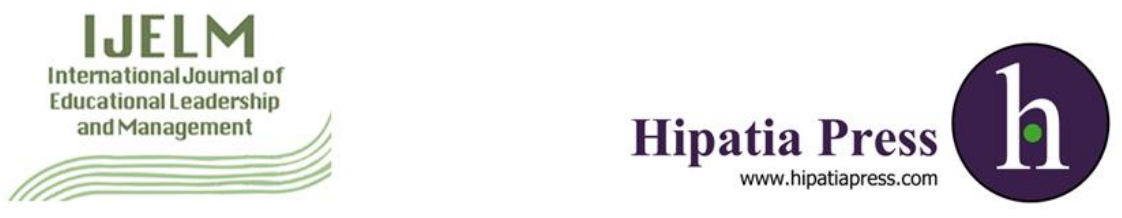

Instructions for authors, subscriptions and further details:

http://ijelm.hipatiapress.com

\title{
Responding to Workplace Absenteeism in Tanzania: The case study of Public and Private Schools in Ilala Municipality and Mkuranga District
}

Michael Greyson Mgonja ${ }^{1}$

1) Mkwawa University. Tanzania

Date of publication: January $16^{\text {th }}, 2017$

Edition period: January 2017-July 2017

To cite this article: Mgonja, M. G.(2017). Responding to Workplace Absenteeism in Tanzania: The case study of Public and Private Schools in Ilala Municipality and Mkuranga District. International Journal of Educational Leadership and Management, 5(1), 88-109. doi: 10.17583/ijelm.2017.2341

To link this article: http://dx.doi.org/10.17583/ijelm.2017.2341

\section{PLEASE SCROLL DOWN FOR ARTICLE}

The terms and conditions of use are related to the Open Journal System and to Creative Commons Attribution License (CCAL). 


\section{Responding to Workplace Absenteeism in Tanzania: The case study of Public and Private Schools in Ilala Municipality and Mkuranga District}

Michael Greyson Mgonja

Mkwawa University

\section{Abstract}

Workplace absenteeism has widely been reported to be a serious problem which undermines smooth service delivery both in developed and developing nations. The problem is reported to be more serious in developing nations. This paper is therefore studying the mechanisms used to mitigate workplace absenteeism, their adequacy and the effective utilization of those mechanisms in public and private schools in Ilala Municipality and Mkuranga District in Tanzania. The study relied on in-depth interviews and documentary review to collect data which was analyzed using excel, content and thematic analysis. This study found numerous measures which have been put in place to deal with teachers' workplace absenteeism both in private and public schools. However, the study found that unlike in private schools, the measures are not seriously executed in public schools. The study recommends that the management of private schools should retain their strictness in dealing with teacher absenteeism. Also, the government should learn the private schools model of dealing with teachers' absenteeism. Hence it should ensure effective utilization of available measures, improve teacher working environment, promotion and paying salary arrears on time. Again heads of schools should stop covering absenteeism behavior of their subordinates. Furthermore public secondary school management structure should be re- organized to introduce field of supervision at a division level.

Keywords: absenteeism; availability and utilization of measures 


\section{Responder al Absentismo en el Lugar de Trabajo en Tanzania: Estudio de Caso de las Escuelas Públicas y Privadas en el Municipio de Ilala y el Distrito de Mkuranga}

Michael Greyson Mgonja

Mkwawa University

\section{Abstract}

El absentismo en el lugar de trabajo ha sido ampliamente reportado como un serio problema que socava la prestación de servicios tanto en países desarrollados como en desarrollo. Se reporta que el problema es más grave en los países en desarrollo. En este artículo se estudian los mecanismos utilizados para mitigar el absentismo en el lugar de trabajo, su adecuación y la utilización efectiva de esos mecanismos en las escuelas públicas y privadas del municipio de Ilala y del distrito de Mkuranga en Tanzania. El estudio se basa en entrevistas en profundidad y revisión documental para recoger datos que se analizaron utilizando excel, y análisis de contenido y temático. Este estudio encontró numerosas medidas puestas en marcha para hacer frente al absentismo del profesorado en el lugar de trabajo tanto en escuelas privadas y públicas. Sin embargo, el estudio encontró que a diferencia de las escuelas privadas, las medidas no se ejecutan seriamente en las escuelas públicas. El estudio recomienda que la gestión de las escuelas privadas mantenga su rigor en tratar el absentismo del profesorado. Además, el gobierno debe aprender del modelo de las escuelas privadas para tratar el absentismo del profesorado. Por tanto, debe garantizar la utilización eficaz de las medidas disponibles, mejorar el entorno de trabajo del profesorado, la promoción y el pago de los atrasos salariales a tiempo. De nuevo, los directores deben dejar de cubrir el comportamiento de absentismo de sus subordinados. Además, se debería reorganizar la estructura de gestión de la escuela secundaria pública para introducir la supervisión a nivel de división.

Palabras clave: absentismo; disponibilidad y utilización de medidas 
Workplace Absenteeism has been widely recounted in various literature as a serious problem facing both developed and developing countries. For example, the report by the Chartered Institute of Personnel Development of 2009 show that at least eight days per employee was lost in 2008 in the UK due to absenteeism (Torrington, 2011). Moreover, Lokke et al., (2007) used data from the European employee index collected from employees selected randomly in 2004 and showed that, the rate of absenteeism in Denmark was 2.8\%, 3.5\% in Norway, 3.9\% in Sweden and $4.6 \%$ in Finland. In all these countries absenteeism was higher in the public sector than in the private sector except for Sweden where there were no difference (Lokkeet al., 2007 cited in Torrington, 2011: 308).

The problem of absenteeism is even worse in Asian and African countries. For example, the 2009 Organization for Economic Co-operation and Development reports on absenteeism show that teachers' absenteeism is high in third world countries (Clotfelter et al., 2007; Miller, 2008 cited in Guerrero et al., 2012). A similar study conducted by Chaudhury et al., (2006) on teacher and health worker's absence in developing countries found the rate of absenteeism to be $16 \%$ in Bangladesh, $25 \%$ in India, 19\% in Indonesia and 27\% in Uganda.

Studies conducted to determine the problem of absenteeism in Tanzania also report high rate of absenteeism. For example, Uwezo Tanzania (2011) Annual Learning Assessment reports that one in five teachers was not present when their school was being assessed. Similarly, the study by the Ministry of Education and Vocational Training of 2010 reports that, the absence rates for surveyed Primary and Secondary schools were $10 \%$ and $13 \%$ respectively. In the same year, HAKI ELIMU conducted a study on teachers' absenteeism and found that, the rate of teachers' absenteeism was $10 \%$ in the visited schools in Tanzania. Tao (2010) argues that a great deal of classroom research in developing countries suggests a deficiency in education quality due to teachers' behaviors such as chronic absenteeism. Again, the study conducted by Betweli (2013) on the nature of teacher professional misconduct in Tanzanian public primary schools in Sumbawanga Region found that absenteeism was among the misconducts committed by teachers in rural and urban areas. More than three quarters of 
pupils and teachers in both rural and urban setting of Sumbawanga Region (i.e. $37 \%$ of teachers and $40 \%$ of pupils in rural and $44 \%$ of teachers and $47 \%$ of pupils in urban) indicate that absenteeism is still a problem (Betweli, 2013). The studies cited above documented illness, low motivation, attending vocational training, hunger, and tiredness among others to be factors that led to absenteeism in Tanzania.

In response to the problem of workplace absenteeism, governments and various agents in different countries have come up with various initiatives for dealing with this problem. For example, at national level, the United Kingdom (UK) government has taken some measures to reduce absenteeism and loss of employment due to sickness by putting two initiatives in place. First, to reduce National Health Service (NHS) costs and invalidity benefits; and, secondly, department of work and pensions arranged a two-year series of job rehabilitation pilot studies. The pilot study aimed at testing three approaches: (a) health care interventions; (b) workplace interventions; and (c) combined interventions (Torrington, 2011: 309).

In India outside actors used camera as a means to control absenteeism where by cameras were given to teachers to take photos of themselves, time stamped in class to prove attendance with pay based on attendance in those photos. This was the randomized control trial conducted by Dunflo et al., (2007) and it seemed to increase attendance; they also used community meeting and school report cards. In Ghana, advice, warning, salary embargo, and transfer of teachers are some of the measures which have been put in place by its Ministry of education as a way of dealing with absenteeism. One study shows that salary embargo is the commonest measure and it has received immediate responses as it affects teachers' lives directly (IBIS/NNED, 2009).

Generally, public and private employers in various countries have undertaken various initiatives to deal with the problem of workplace absenteeism. However, most of those initiatives are most likely to give temporary solution to the problem. For example, salary embargo and transfer cannot permanently resolve ill-related absenteeism or absenteeism caused by low employee's motivation. It can only give a temporary solution to the problem but the situation is likely to recur as the employees become ill and 
as employee motivation sink down. So, there is a need of looking into the problem for permanent solution.

Absenteeism in Tanzania is also reported as a chronic and serious issue because it undermines productivity and service delivery in various institutions. However, existing studies do not show initiatives or measures put in place by employers in Tanzania to seriously deal with the absenteeism problem. This impunity gives rise to some questions like: what measures have been used by employers in response to workplace absenteeism? If they exist and are applied, how effective are those measures? Why does chronic absenteeism still persist?

This paper, therefore, examines the measures taken by the employers and other education stakeholders to address the problem in Tanzania. It should be noted that employers pay employees in exchange for work. This paper is organized in five sections; following this introduction section two presents the conceptual framework which shows the manifestation of workplace absenteeism and possible way of dealing with it followed by section three which describes the methodology used by this paper. Section four presents and discusses the findings of this study followed by some concluding remarks at the end.

\section{Conceptual Framework}

In the light of various literature studied, the researcher constructed the conceptual framework (Figure 1) which gives a picture and direction when dealing with the problem of workplace absenteeism. In this regard, the current study was framed under the following explanatory variables which basically explain absenteeism problem and ways of mitigating it.

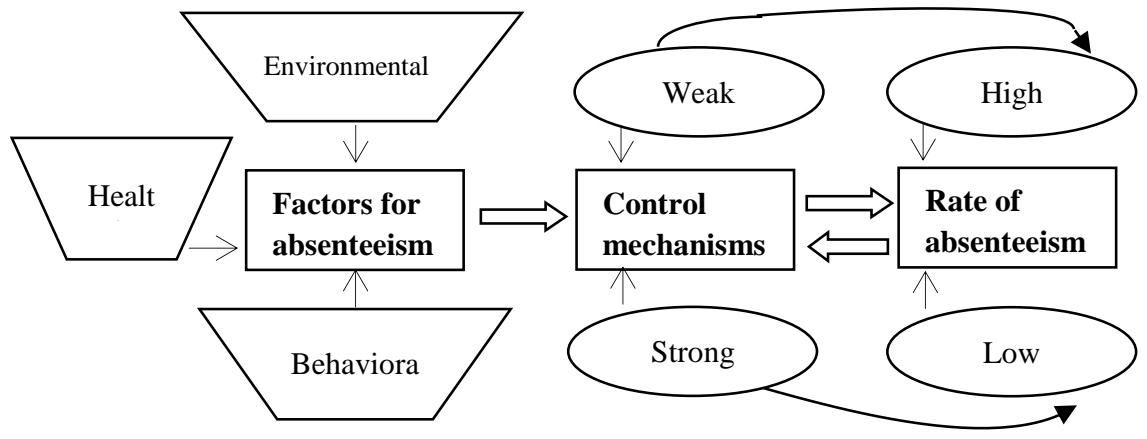


Figure 1. Manifestation of Workplace Absenteeism. Source: Author

\section{Factors Leading to Absenteeism}

Figure 1 above shows that there are various factors which may lead to employees' absenteeism such as health problems, environmental factors such as distance from workplace, transport problems, relationship with management and other workers; Individual behaviors such as commitment with the job, individual life style, like too much drinking of alcohol and drug abuse. These factors may differ from one organization to another.

\section{Control Mechanisms}

Factors leading to absenteeism can be controlled if control mechanisms are put in place. Control mechanisms can be positive or negative as follows:

Positive control mechanisms: the assumption is that employees are likely to show up to their work as per contract if there are strong positive control mechanisms in place to influence them to attend. Examples of positive control mechanisms may include rewards, recognition, good working environment, and attendance bonuses (Robbins et al., 2003; Aamodt, 2004; Rhodes and Seers, 1990 in Josias, 2005; Vroom, 1964). Positive control mechanism aim at encouraging positive behaviours of an employee in the organization.

Negative control mechanisms: these are disciplinary measures which should be put in place. They may include sanctioning, warning, and calling employees with high rate of absenteeism in disciplinary meeting, etc. Negative control mechanisms aim to discouraging undesirable behaviors of employees.

Weak control mechanism: this can be a delay of absenteeism report, delay of disciplinary measures, lack of attendance rewards and bonuses. Absenteeism 
rate is likely to be high if organization absenteeism control mechanism is weak or not utilized properly.

Strong control mechanism: this is the efficient and effective utilization of the available measures to control absenteeism and creating thinking on the best way of dealing with any new kind of absenteeism arising. It involves proper utilization of available measures to control absenteeism like warning, keeping attendance register, transfer, salary deduction, salary embargo, rewards, attendance bonuses, recognition, timely payment of salaries and arrears just to mention a few. This model suggests that the rate of absenteeism is likely to be low if an organization absenteeism control mechanism is strong.

\section{Absenteeism Rate}

The rate of absenteeism is highly affected by control mechanisms which have been put in place to resolve the problem. If control mechanisms are strong, it is likely that absenteeism rate will be low and vice versa if control mechanisms are weak. The organization management may decide to change or to modify control mechanism to respond to absenteeism situation available.

\section{Methodological Issues}

This study employed the case study design basing on qualitative approaches in collecting and analyzing data. Qualitative approach was the best as it helped researcher to drill in-depth understanding of teachers' absenteeism and reasons that govern such behaviour. Qualitative approach always answers descriptive and analytical research questions like where, when, which, how, why and under what circumstances a behaviour comes into being (Bogdan and Biklen 2006, Kothari 2004 ). This study was conducted in two purposefully selected areas of Tanzania mainland, Mkuranga in Pwani Region and Ilala District in Dar es Salaam. The study areas were selected based on rural-urban divide. These differences in terms of geographical location were targeted to help the researcher to make comparisons. 
The targeted population in this study was employers of public and private schools and educational administrators including district education officers, Teacher's Service Departments (TSD), secondary schools inspectorate, ward education officers and heads of schools. Ordinary teachers were also included in this study.

The study employed purposive sampling and random sampling techniques. This was because of limited time, fund and kind of data the researcher wanted to obtain. The sample was drawn from both private and public secondary schools. Four Secondary Schools were randomly selected in each District. Selection of schools was done based on two clusters (centre and Peripheral). That is, two private and two public secondary schools from center of the Mkuranga District, and other two public and two private schools from peripheral. The same applied to Ilala Municipality.

This study used in-depth interviews and documentary review to collect data. The documents reviewed were teachers' attendance register books, Public Service Standing Order of 2009, Circulars from Tanzania Public Service Secretariat which show the power of TSD to head of secondary schools; warning letters given and class journals. These documents helped to generate a deeper understanding of the problem of employee absenteeism. The rationale for employing both methods was to complement each other so as to increase the validity of data.

\section{Responses to Workplace Absenteeism in the Study Areas}

This section focuses measures which have been put in place by employers in Ilala Municipality and Mkuranga District in response to the teachers' absenteeism.

The findings of the study show that, all respondents interviewed in both study areas agreed and documents reviewed revealed that, several measures have been taken against teachers' absenteeism. The execution of the measures involves two levels: school management and central government management level depending on the severity of the problem. The introduction and execution of those measures in public sector is based on the power vested onto both school and district management, which is clearly stipulated in section "F" of the Public Service Standing Order of 2009. This 
section shows various rules of the game in the public arena such as rules concerning office hours and Attendance Registers, Absence from duty on ground of illness, absence without permission, disciplinary authorities and disciplinary procedures, and dismissal, among others. Absenteeism control measures in place in both Ilala and Mkuranga are detailed below.

\section{Teachers' Attendance Registers}

It is clearly stated in section "F2" of the Public service standing order (2009), that in order to maintain a record of the time of arrival of public servants on duty, attendance registers shall be maintained by a public organization. The register should be signed by members of staff at all levels employed in offices, teaching institutions, hospitals, etc. except those who are required to work in "shifts" (Tanzania Public Service Standing Order, 2009) . In this case, section "F" of the Public service standing order gives power to school management to introduce attendance registers which have to be signed by all teachers every day when they arrive to their workplace. In order to ensure the effectiveness of the attendance register, the same section of the standing order gives various directives to supervisors including drawing lines below the last signature of employee:

The supervising officer in the office, institution etc. shall be responsible for the proper maintenance of the register which shall usually be kept at a convenient place in the office premises. He shall ensure that the register is available for signature as follows:

(a) Before the commencement of every working session; a blue or black line shall be drawn at 7.30 a.m. immediately below the last signature of public servants who have signed the register, and Column 5 of the register shall be signed;

(b) After the commencement of the working session, a red line shall be drawn at 7.40 a.m. immediately below the last signature of the public servants who have signed the register and column 5 of the register shall be signed;

(c) The register shall be withdrawn at 8.00 a.m. and public servants who report for duty after the attendance register has been withdrawn shall report to the supervising officer and sign the register in his presence 
d) Approved late attendance shall be recorded by the supervising officer in the remarks column; and

(e) The supervising officer shall submit the attendance register to the Head of Division or Institution for inspection on the 15th and 30th day of every month. (Tanzania Public Service Standing Order, 2009: 114).

Furthermore, the mechanism against the employees who leave before normal official time of closing the office has been put in place. The supervising officers are directed to let employees sign whenever they encounter a problem which cause them to leave the office before official close of business.

...In order to maintain a record of the time public servants spend outside the office before the official closing time a special register shall be maintained by an organization in the Form set out in Appendix F/II. Public servants shall be required to sign this special register when they leave the office during office hours and record the time they leave, the approximate time they shall be staying out, the business they shall transact during the time of absence and the actual time they report back to the office.

(Tanzania Public Service Standing Order, 2009: 114).

Attendance registers are used both as a tool to identify attendance behavior of the employees and also as a mechanism to discourage absenteeism. It is this signed document which is used to prove employee absenteeism whenever a case is to be judged.

Based on the same ground employers in Ilala Municipality and Mkuranga District have introduced the attendance registers to control the teachers' attendance in their work place. However, the attendance register are not in exact format as that directed in the Public service standing order of 2009. For instance, the format of attendance register demonstrated in the Public service standing order of 2009 show seven (7) columns to be filled but there are disparities of the format of actual attendance register signed by teachers in schools. Some of attendance registers in schools show six columns and others five to be completed. See tables one to three below which show those discrepancies. 
98 Mgonja-Responding to Workplace Absenteeism in Tanzania

Table 1

Attendance Registers' Format as Shown in the Public Service Standing Order of 2009

Source: Tanzania Public Service Standing Order, (2009:137).

Ministry/ independent Department/Region/Local Government Authority............ Date......................... Division/Section

\begin{tabular}{|l|l|l|l|l|l|l|}
\hline S/N & Name & $\begin{array}{l}\text { Designation/ } \\
\text { Post held }\end{array}$ & $\begin{array}{l}\text { Time of } \\
\text { reporting }\end{array}$ & Signature & \multicolumn{2}{|l|}{$\begin{array}{l}\text { FOR OFFICIAL USE } \\
\text { ONLY }\end{array}$} \\
\cline { 3 - 7 } & & $\begin{array}{l}\text { Supervisor's } \\
\text { signature }\end{array}$ & Remarks \\
\hline$(1)$ & $(2)$ & $(3)$ & $(4)$ & $(5)$ & $(6)$ & $(7)$ \\
\hline
\end{tabular}

Table 2

The $1^{\text {st }}$ Format of Actual Attendance Registers Signed at Schools

Source: Documents reviewed in the field,March 2014.

\begin{tabular}{|l|l|l|l|l|}
\hline S/N & Date & Name & Reporting time & Signature \\
\hline$(1)$ & $(2)$ & $(3)$ & $(4)$ & $(5)$ \\
\hline
\end{tabular}

Table 3

The $2^{\text {nd }}$ Format of Actual Attendance Registers Signed at Schools

Source: Documents reviewed in the field, March 2014.

\begin{tabular}{|l|l|l|l|l|l|}
\hline S/N & Date & Name & Title & $\begin{array}{l}\text { Reporting } \\
\text { time }\end{array}$ & Signature \\
\hline$(1)$ & $(2)$ & $(3)$ & $(4)$ & $(5)$ & $(6)$ \\
\hline
\end{tabular}

These variations have a legal implication if the absenteeism case has to be presented before the administrative tribunals. The attendance registers signed in schools are not formal as they differ from the one directed in the Public service standing order of 2009 which is the mother law guiding the management of public servants. Various heads of schools interviewed in this study are now contemplating on introducing the formal registers: 
...we are now introducing the formal attendance register for teachers to sign because those which they are signing are not formal, they lack the legal back up as it differ from that directed in the Public standing order of 2009. This weakness can give the employee power to challenge the judgment in the court especially when it happens that he or she has been sued for absenteeism and subjected to dismissal and of course this is not abstract it happened in one of the regions I have worked

(Interview, March 2014)

Also findings show that school management is not submitting attendance report twice in a month to their superior as it is directed in the standing order. Instead they just observe and identify teachers whose attendances are not good and take various measures against their behavior through their office or through school disciplinary committees. At the end of the month the calculation is made to get attendance rate of the teachers per month, then they write a report and send to the district management or to the school managers for private schools. This finding corresponds with that of the study conducted by Chediel (2010) which found out that head teachers resolve cases of absenteeism locally instead of reporting to the high level of authorities (Chediel, 2010).

This implies that the available rules and regulations to maintain discipline of teachers in various disciplinary issues like absenteeism are not used as directed. In short school management does not adhere exactly to the official rules and regulations available.

\section{Warning}

Employers in Ilala Municipality and Mkuranga District use warning as a response to work place absenteeism. They start with verbal warning at school management level especially in the tea meetings followed by written warning if the problem persists. Warning letters are written and signed by heads of school before they are delivered to the teacher and the copy is made to a teacher's official file and to the head masters/mistresses' files. One of the head of school in Ilala District informed the researcher that; 
We respond to teachers' absenteeism in various ways but we normally start by verbal warning followed by written warning if the behavior persists. As we are talking here, twenty teachers have been given written warning today

(Interview, March 2014)

If the behavior persists, the school management reports to the district level management for the public schools and to the school managers for the private schools. Here the management decides on the best way of dealing with the problem. They can also summon a particular employee and order him or her to give a written explanation on why he or she should not be subjected to disciplinary procedures. If the management is satisfied with her or his explanation they decide either to give him or her verbal or written warning. Furthermore, findings show that warning is the common measure used to deal with employee absenteeism in Ilala Municipality and Mkuranga District.

\section{Stopping Payments (SP) and Salary Deduction (SD)}

This is another measure used by employers in Ilala Municipality and Mkuranga District to deal with teachers' absenteeism. Teachers reported to be absent from work for at least one month without any information are subjected to this measure. In the private schools, the days a teacher has been absent from work are calculated and a salary deducted accordingly. If the behavior persists to the next month the other serious measure is applied e.g. dismissal. Unlike India where teachers payments are pegged to photos of the teachers taken during teaching in the class (Dunflo et al, 2007) teachers' attendance records is the base of payment in Ilala Municipality and Mkuranga District private schools. One of the head teachers in a private school had this to say:

If teacher(s) is not in the workplace for one week and above we calculate the day he/she attended at the end of the month and pay him or her accordingly and if the behavior persists dismissal measure fall upon him/her. In this way, teachers' 
attendance has been improved because no one is ready to receive the deducted salary.

(Interview, March 2014)

Like in other literature (for example, IBIS/NNED, 2009) findings show that SP and SD receive the immediate response from the employee because it touches things which are highly valued by an employee (SP and SD affect teachers' lives directly). Therefore, unless teachers get other means of earning they always come back to their work station soon after discovering that the salary has been stopped or will be deducted.

This implies that application of painful measures like salary embargo or salary deduction in controlling teachers' absenteeism work better than application of the soft measures like verbal warning. If the payment in both private and public schools should base on their attendance, the good attendance will be maintained. However, unless other methods are used to assist the former it is likely to face a lot of challenges during its implementation e.g. teachers are likely to focus much on attendance than teaching as it is their base of payment. Also, it is very difficult to keep correct records in a country with low technology like Tanzania. Moreover, workers who process employees' salaries are very few so it would be very difficult for them to pass through the file of every employee and process their monthly payments in effect of employees' attendance.

\section{Dismissal}

Tanzania Public Service Standing Order 2009, section 120 states that, "Where a public servant is absent from duty without leave or reasonable cause for a period exceeding five days, that public servant may be charged with the disciplinary offence of being absent without leave and punished by dismissal". With the rate observed by this study in the study areas we could expect dismissal of many absent teachers if this measure was to be effectively utilized. However, findings show that, this measure is taken up on teachers who have been absent from their work place for long time. For instance, TSD revealed that out of 15 teachers' absenteeism cases reported in Mkuranga Districts in 2013, only one teacher was dismissed from work. In Ilala Municipality the reported cases were 17 and all of them were only given written warning. No new case of absenteeism was reported to TSD for 
disciplinary measures up to March 2014 when the study was conducted although the document reviewed still show high rate of absenteeism. It is the TSD disciplinary meeting which decides the dismissal of teacher(s) after receiving a claim from the employers. In most of the private schools dismissal of the employees is suggested by head teachers and approved by school managers. Furthermore, the process takes a very short time to be accomplished in private schools because its chain of implementation is not as long as in public schools.

This implies that there are management problems in these study areas especially in public schools where the stated measures are not put on effect the way they should be until the situation becomes worse. And even when they decide to exercise it, they apply for the workers who have been absent for a long time and the process takes a very long time.

\section{Controlling Employees Loans through LAWSON System}

Another mechanism used to control absenteeism is to make sure that employees are not taking loans higher than they can repay from their salaries. Findings show that management in Ilala municipality is using LAWSON to make sure no employee takes loans beyond three quarter of their basic pay. The aim is to make sure that even if employees take loans from various financial institutions they should remain with some amount of salary which will help them to survive. This remaining amount will give them incentive of attending to work place, unlike when the whole salary has been taken to repay the debts. According to Ilala Municipal management, this mechanism has succeeded to reduce the rate of absenteeism caused by employees' big loans which influence them to find other sources of earning income.

Although LAWSON is not a new thing in Mkuranga District, it seems it is not used as a tool of controlling employees from taking big loans. The system of LAWSON is not the case in private schools where employee loans do not involve their employers.

\section{Using Motivation Mechanisms}


Findings indicate that teachers, especially those working in private schools in Ilala Municipality and Mkuranga District, are motivated in various ways. Such motivators include increase of payments and performance bonuses after the announcement of national examinations results. One of the respondents in private schools had this to say:

... at least our management motivates us in various ways. For example, we get lunch here at school.Alsothere are performance bonuses in this school which is given according to the performance of students in one's class (Interview, March 2014)

This mechanism seems to receive positive response from the employees because everyone is struggling for those allowances hence good attendance. However, the interviewed respondents in public schools reported that no rewards or allowances apart from the meagre monthly salaries have been delivered to them since the first appointment. Moreover, their salary arrears and debts are not paid on time. This situation results in teachers' absenteeism as some of them find other means to increase their earning.

These findings are supported by Expectance theory which explains the importance of rewarding employees in workplace (Vroom, 1964). Vroom (1968) assumes that employees are likely to behave positively in the work place if the rewards are in place. This implies that unless motivation is put in place teachers absenteeism will keep on mounting.

\section{Delegation of Teachers Department Power (TSD) to School Head Teachers}

In order to bring effectiveness and close management of teacher's behaviors including teachers' absenteeism, the government has decided to delegate TSD powers to heads of schools. With the circular ${ }^{1}$ sent to them, heads of schools are now allowed to charge various disciplinary cases and give various punishments except dismissing the employee from his or her employment. This is the recent measure which has been imposed by the

${ }^{1}$ Ref. No. CFA 142/355/01/68 of $4^{\text {th }}$ March, 2013 
government to deal with various teachers' misconducts including absenteeism. However, one wonders if this mechanism will be feasible because the same persons to whom power has been delegated are blamed for late or not reporting the problems like teachers absenteeism to the district management level. Therefore, the problem is likely to persist because it is unlikely that heads of schools will effectively administer disciplinary cases as required.

\section{Adequacy and Utilization of Available Measures}

This part of the study explores the adequacy of the measures put in place to address the problem of teachers' absenteeism. Adequacy of the measure in this study refers to the number, scope and type of absenteeism control mechanisms in place. The actual utilization of the measure was explored in order to know whether those available measures are utilized effectively or are not utilized at all. In this case utilization of the measures refers to actual actions undertaken to address absenteeism as prescribed in the measures.

\section{Adequacy of the Measures}

Table 18 shows the summary of the views of respondents in Mkuranga District and Ilala Municipality on whether the measures that have been put in place to deal with absenteeism are adequate or not.

Table 4

A summary of the responses from Management and Ordinary Teachers on measures put in place to deal with absenteeism

\begin{tabular}{ccllll}
\hline \multicolumn{2}{l}{ Study areas } & \multicolumn{2}{l}{ Mkuranga District } & \multicolumn{2}{l}{ Ilala Municipality } \\
S/ & Respondents views & Frequency & Percentage & Frequency & Percentage \\
N & & & & & \\
1 & Adequate measures & 26 & $93 \%$ & 27 & $96 \%$ \\
2 & In adequate measures & 2 & $7 \%$ & 1 & $4 \%$ \\
3 & No measures & - & - & - & - \\
\hline & Total (N) & 28 & $100 \%$ & 28 & $100 \%$ \\
\hline
\end{tabular}

Source; Interview in Ilala Municipality and Mkuranga District, in March, 2014 
Majority of ordinary teachers and management staff interviewed in both study areas show that, there are adequate measures put in place in both study areas to control teachers' absenteeism. For instance, $96 \%$ of respondents in Ilala Municipality and 93\% in Mkuranga District agreed on the existence of adequate measures to control teachers' absenteeism. They are adequate in number and in scope as they at least cover every angle of absenteeism which is common in their schools. One of the ordinary teachers interviewed said the following:

There are a lot of measures like signing attendance register book, warning letters, stoppage of salaries, advice which have been put in place to mitigate teachers' absenteeism in our school. Also, sometimes we use tea breaks to discuss informally and discourage teachers' absenteeism as we know its impact on the performance of our students.

(Interview, March 2014)

When public and private responses were disaggregated from the general finding, it was observed that more than three quarters of public and all private school teachers interviewed in both study areas are of the view that there are adequate measures put in place to deal with teachers' absenteeism. Likewise, about all school and ward/ district management staff from both public and private schools management interviewed were in line with this argument. One of the management staff had this to say:

I think the available measures are enough to deal with this problem. As you can see here we have different types of warning letterswhich can be issued to teachers depending on the type of absenteeism behaviour he or she has exhibited. We have also other measures like transfer, stoppage of payments and dismissal but this is done by our superiors (district management level) after we have reported the absenteeism cases that seemed to be chronic. (Interview, March 2014).

This implies that the current problem of absenteeism in those study areas is not caused by inexistence of the measures as measures seem to be adequate. In this case there might be some other different reasons which 
cause the problem to persist. The problem may be on the extent of utilization of the measures as the findings indicate in the subsequent sub-section.

\section{Utilization of absenteeism control Measures}

Availability of adequate measures to deal with the problem is one thing and actual utilization of those measures is another. Although documents reviewed verify existence of enough mechanisms and responses of the respondents interviewed support the adequacy of measures to control teachers' absenteeism, the effective utilization of those measures in public secondary schools in both study areas is questionable.

For example, although section "F" of the third edition of the Standing orders for public service (2009) state clearly the disciplinary measures to be undertaken in various misconducts including employees absenteeism, the rates of teachers absenteeism in the study areas are very high compared to the rates of teachers punished by school management or cases reported in district and central government level for disciplinary measures. Majority of ordinary teachers and school management and ward/ district management staff $(68 \%$ and $57 \%$ in Mkuranga District and Ilala Municipality respectively) interviewed, reported that no absent teacher was punished in the past two months before March 2014.One of the respondents from management staff said the following;

No! There are no absent teacher(s) who have been punished in the past two months of this year (2014). Also no one has been reported to district management because the problem has not yet become chronic to anyone in this New Year

(Interview, March 2014)

As reported above, although absenteeism persists, measures to mitigate the problem are not seriously executed especially in public schools. Only few schools reported one or two absent teachers that have been punished for being absent. Findings in both study areas revealed that, even those few punished or reported cases to District and central government level for disciplinary measures, are among those of teachers who have been absent for 
a very long period of time. For instance, while absenteeism rate among public school teachers were $40 \%$ and $16 \%$ in Mkuranga District and Ilala Municipality respectively in 2013, the information from TSD showed that, the reported cases to district and central governmentfor disciplinary measures were only $4 \%$ in Mkuranga District and 1\% in Ilala Municipality. This implies that school management which is highly informed of teachers' absenteeism cover the problem until it becomes chronic to someone to the extent that it can be discovered by their superiors. However, if this problem persists for a long time students' performance is likely to be highly affected.

The study findings also indicate that, there are delays of action taken on the reported absenteeism cases to the central and district management levels. It takes a very long time for disciplinary meetings to be held while the teacher is absent from work for more than three months and he or she is still paid by the government. One respondent in one of the schools had the following to say:

It is five months now since I have reported the absenteeism of one of the teachers in my school but until this time he is still paid the government salary while he is not in the workplace.

(Interview, March 2014)

This means that even when the problem is reported disciplinary actions are not taken immediately. Perhaps, this situation discourages school management officials; thus, they decide to delay until the problem becomes chronic.

Furthermore, the district and central government management level reported that disciplinary meetings are usually held after every three months to discuss different disciplinary cases reported including teachers' absenteeism. However, sometimes, more than six months go without conducting such meetings. This is due to the shortage of fund for paying members of the meeting as this meeting involves members from outside TSD department. However, district management is expected to stop immediately salary payment to the teacher while waiting for disciplinary meeting for judgment. One of the TSD staff had this to say: 
We normally conduct the disciplinary meeting in every three months. However, it is more than six months now the meeting has not been conducted. This happens sometimes due to the shortage of funds to pay members of the meeting. We can think of conducting the meeting even without cash payment but this meeting comprise of members from other departments so it becomes very difficult to organize a meeting without money.

(Interview, March 2014)

This situation does not only affect government as they pay ghost workers but also students' performance is largely affected.

Moreover, there is also no balance in the utilization of the available measures. It is "warning" which is dominant in dealing with this problem. Other stern measures like stopping payment (SP) and dismissal are rarely applied and only for teachers who have been absent from their work places for a very long period of time contrary to the directives of the 2009 Tanzania Public Service Standing Order. This has led teachers to conclude that, it is very difficult for their salary to be cut off or for them to be dismissed from work for absenteeism cases.

Furthermore, there is no close follow-up on the conduct of these school management officials. The secondary schools' inspectors are very far from schools and overloaded as they deal with all secondary schools in a Zonal basis which is more than one region or many districts. For instance the eastern Zone comprises of Morogoro and Coast region despite the limited number of school inspectors. Some schools have not even had a visit from zonal school inspectors for more than two years. One of the respondents had this to say:

...it is three years since I have been employed in this school; I have never seen zonal secondary school inspectors come to visit my school.

(Interview March, 2014).

This finding has been corroborated by one of respondent in zonal schools inspector who said the following:

...we are very few in number and we have many schools to inspect in Morogoro and Coast region. Some of the schools are far into the interior; at 
the same time no enough money is budgeted for buying fuel and paying allowances for inspectors, so we always only visit few schools.

(Interview March, 2014)

Moreover, these inspectors do not have enough power to take any direct disciplinary measures to teachers who are found with an offence. They have only advisory power to employers. It is then upon the employers to take measures or not.

The district management level which is also not close enough to oversee the action of secondary school management level is the only organ which is expected to do it regularly. At the same time these officials are not visiting these schools regularly for the reason that there is shortage of fund for financing the travel and allowances of officials to visit those schools regularly. Also they are busy with other duties in the office so most of the time they are waiting for reports from school management. Ward education coordinators who could be the preferable personnel to oversee the actions of the school management are only responsible to oversee the primary school management i.e no ward secondary schools education coordinators.

This implies that despite the management problems available there are also structural problems which to some extent contribute to the persistence of the problem. Unlike in public schools, private management of all levels seems to be very serious in dealing with teachers' absenteeism. This can be marked by the low rates of teachers' absenteeism which has not exceeded $5 \%$ in both study areas.

\section{Conclusion and Recommendations}

This study draws the following conclusions. One, this study has discovered a high rate of absenteeism in Mkuranga and Ilala Districts despite of adequate measures put in place to control teachers absenteeism in both private and public schools. However, the enforcement of the available measures is not adequate in public schools compared to its private counterpart. Two, Teacher motivation is not adequately used in managing teachers' attendance behaviors in public schools. This contributes to higher rate of absenteeism in these schools compared to private schools. 


\section{Recommendations}

This study recommend the following issues. First, the private schools management should retain their strictness in dealing with teachers' absenteeism which has discouraged absenteeism in these schools. Secondly, the government should emulate the private schools model of dealing with teachers' absenteeism; hence it needs to ensure that the available measures to mitigate employee's absenteeism are effectively utilized. Thirdly, government should improve motivation to teachers by improving their working environment, paying their salary arrears on time, increase salaries and other benefits in line with the duties they perform. Fourthly, teachers should adhere to their professional code of ethics. In this way, heads of schools need to be reminded of their roles and encouraged to stop covering absenteeism behaviors of their subordinates. Lastly, the secondary school management structure would need to be re-organized to introduce field of supervision that would monitor secondary school at least at the level of a division. This is likely to reduce the risk of only relying on districts and zonal school inspectorate units in overseeing the schools management level in managing teachers' absenteeism behaviors.

\section{References}

Betweli, O. (2013). The Nature of Teacher Professional Misconduct in Tanzania Public Primary Schools: The Case of Sumbawanga Municipality and Rural Districts. International Journal of Education, 5(1), 81-93. DOI: http://dx.doi.org/10.5296/ije.v5i1.3291

Bogdan, C and Bilken, K. (2006), "Qualitative Research for Education; An Introduction to TheoriesModels,"www.jkarahalisi.com/default/files/part2 chapterQualititativeResearchforEducation.pdf.

Chaudhury, N., Jeffrey, H., Kremer, Muralidharan, M., K \& Rogers, H. (2006). Missing in Action: Teacher and Health Worker Absence in Developing Countries. Journal of Economic Perspectives, 20 (1), 91116.

Chediel, R. W. (2010). Teachers Management in Context of HIV and AIDS, Tanzania Report. Unpublished Manuscript, Paris: UNESCO-IIEP. 
Clotfelter, Charles, Ladd, Helen, \& Vigdor, Job, (2007), Are Teachers absences worth worrying about in the U.S? http://www.nber.org/papers/w13648 JEL No. I21

Dunflo, E., Hanna R. \& Ryan, S.P. (2007). Monitoring Works: Getting Teachers to Come to School. India: CEPR, Discussion Paper.

Guerrero G., Leon, J., Zapata, M., Sugimaru, C. \& Cueto, S. (2012). What Works to Improve Teacher Attendance in Developing Countries? A systematic review. London: EPPICentre,Social Science Research Unit, Institute of Education, University of London.

Hakielimu. (2010). Annual Report. Dar es Salaam: Hakielimu.

IBIS/NNED. (2009). An Assessment of Effects of Teacher Absenteeism on Quality Teaching and Learning in Public Schools in Northern Ghana. Retrieved from http://siterosources.worldbank.org/intafregtopeducation/Resources12 2226591212165/ed.

Josias, A. B. (2005), "The Relationship between Job Satisfaction and Absenteeism in aSelected field Services within an Electricity utility in the Western Cape," University of Western Cape, www.verfloller.nl/rio.pdf, (Accessed: 12 ${ }^{\text {th }}$, May, 2013) Kothari, R.C. (2004). Research Methodology; Methods and Technique. India: New Age International (p) Limited.

Ministry of Education and Vocational Training, United Republic of Tanzania, (2010). Annual Report. Dar es Salaam; MoEVT

Tao, S. (2010). Applying the Capability Approach to School Improvement Interventions in Tanzania. Institute of Education: University of London.

The United Republic of Tanzania , (2009). Standing Order for the Public Service;

Third Edition, Dar es Salaam: Government Printer

Torrington, D., Hall, L., Taylor, S. \& Atkinson, C. (2011). Human resource management. London: FT/Prentice Hall.

Uwezo Tanzania. (2011). Are our Students Learning? Annual Learning Assessment Report Tanzania. Tanzania: Uwezo, http://www.uwezo.net/wpcontent/uploads/2012/08/TZ 2011_Annual Assessment-Report.pdf

Vroom, V. (1964). Work and Motivation. New York: Johns Wiley and Sons.

Michael Greyson Mgonja, Position: Assistant Lecturer, 
112 Mgonja-Responding to Workplace Absenteeism in Tanzania

Political Science and Public Administration Unit, Mkwawa University.

Contact Address: Box 2513. Iringa - Tanzania.

E-mail:michaelmgonja@rocketmail.com 